\title{
Analisa Faktor-faktor yang Mempengaruhi Ketersediaan Bahan Pangan dalam Pengambilan Kebijakan dan Keputusan BKP Provinsi Riau
}

\author{
Misra Hartati ${ }^{1}$, Nurul Azmi ${ }^{2}$ \\ ${ }^{1,2}$ Jurusan Teknik Industri, Fakultas Sains dan Teknologi, UIN Sultan Syarif Kasim Riau \\ Jl. HR. Soebrantas No. 155 Simpang Baru, Panam, Pekanbaru, 28293 \\ Email: misrahartati@gmail.com \\ Email: nurul elfishy@yahoo.co.id
}

\begin{abstract}
ABSTRAK
Saat ini, ketersediaan bahan pangan Provinsi Riau sangat terancam. Hal ini dikarenakan adanya kekurangan bahan pangan yang menyebabkan kebutuhan pangan masyarakan belum dapat terpenuhi, terutama bahan pangan jagung. Oleh karena itu, pihak BKP Provinsi Riau harus mencari cara untuk meningkatkan ketersediaan bahan pangan jagung demi mensejahterakan masyarakatnya. Untuk mencapai tujuan tersebut, maka harus diketahui terlebih dahulu faktor-faktor apa saja yang mempengaruhi ketersediaan bahan pangan jagung. Penelitian ini dilakukan untuk menganalisis faktor-faktor yang mempengaruhi ketersediaan bahan pangan jagung di Provinsi Riau. Penelitian ini menggunakan data yang berkaitan dengan ketersediaan jagung Provinsi Riau dari tahun 2005-2015. Metode analisis data yang digunakan dalam penelitian ini adalah model regresi linear berganda. Dari hasil penelitian diperoleh bahwa ketersediaan jagung di Provinsi Riau secara serentak (Uji F) dipengaruhi oleh luas panen, harga domestik, jumlah penduduk dan tenaga kerja. Secara parsial (Uji T) dipengaruhi oleh luas panen dan jumlah penduduk, sedangkan harga domestik dan jumlah tenaga kerja tidak mempengaruhi ketersediaan jagung. Kemudian dilakukan analisa FTA (Fault Tree Analysis) untuk mendapatkan kebijakan yang tepat untuk BKP Provinsi Riau. Kebijakan yang dapat dilakukan yaitu kebijakan pemberian subsidi benih untuk petani dan kebijakan evaluasi kinerja pegawai dalam pendistribusian benih subsidi. Oleh karena itu, dengan adanya kebijakan ini diharapkan pemerintah dapat mengimplementasikannya agar ketersediaan bahan pangan jagung Provinsi Riau terpenuhi.
\end{abstract}

Kata Kunci : Fault Tree Analysis, Kebijakan, Ketersediaan Bahan Pangan Jagung, Regresi Linier Berganda

\section{ABSTRACT}

At this moment, availability of food in Province Riau was threatened. It because that there is shortage of food who make food needs of people have not been met, especially corn food. Therefore, BKP Province Riau must look for ways to improve the availability of corn food for prospering the community. To reach this goal, firstly we must know that what influence availability of corn food. This research goal is to analysis factors that influence availability of corn food Province Riau. In this research use data that have relationship with avaibility of corn food Province Riau on 2005-2015. Data analysis method is used that multiple linear regression model. From the result in this research is gotten that avaibility of corn food Province Riau based on simultaneously (F Test) is affected by harvested area, domestic price, total population and total manpower. Based on partially (T Test) is affected by harvested area and total population, while domestic price and total manpower do not affect the avaibility of corn food. Then, do analysis FTA (Fault Tree Analysis) to get the right policy for BKP Province Riau. The policies that can be done is policy of seed subsidy for farmers and policy of evaluation's civil servant work in distribution of seed subsidy. Therefore, with this policy is hoped the Government can implement it in order the availability of corn food Province Riau can be fulfilled.

Key Word : Availability of Corn Food, Fault Tree Analysis, Multiple Linear Regression, Policy 


\section{Pendahuluan}

Visi Dinas Badan Ketahanan Pangan Provinsi Riau adalah "Terwujudnya Lembaga yang Handal Dalam Memantapkan Ketahanan Pangan Masyarakat yang Berbasis Sumber Daya Lokal Menuju Kemandirian Pangan" (Badan Ketahanan Pangan Provinsi Riau, 2017).

Menurut Badan Ketahanan Pangan (BKP) Riau, Darmansyah, 70 persen masalah ketahanan pangan di Riau bergantung pada provinsi tetangga. Tentunya kalau Riau hanya bertahan dengan posisi 30 ketersediaan pangan, diyakini ketersediaan itu tidak akan cukup untuk mengatasi kebutuhan masyarakat.

Data Ketersediaan akhir komoditi pangan Provinsi Riau Tahun 2010-2015, menunjukkan jumlah ketersediaan akhir yang dimiliki oleh Provinsi Riau dari jumlah produksi dan jumlah impor dari provinsi tetangga, yaitu sebagai berikut.

Tabel 1. Data ketersediaan akhir komoditi pangan provinsi riau tahun 2010-2015 (ton)

\begin{tabular}{|l|c|c|c|c|c|c|}
\hline $\begin{array}{l}\text { Komod } \\
\begin{array}{c}\text { iti } \\
\text { Pangan }\end{array}\end{array}$ & $\mathbf{2 0 1 0}$ & $\mathbf{2 0 1 1}$ & $\mathbf{2 0 1 2}$ & $\mathbf{2 0 1 3}$ & $\mathbf{2 0 1 4}$ & $\mathbf{2 0 1 5}$ \\
\hline Beras & 270.402 & 236.737 & 209.652 & 176.672 & 171.587 & 177.185 \\
\hline Jagung & 511 & $(9.755)$ & $(7.825)$ & $\begin{array}{c}(11.286 \\
)\end{array}$ & $\left(\begin{array}{c}15.480 \\
)\end{array}\right.$ & $\begin{array}{c}10.672 \\
)\end{array}$ \\
\hline Kedelai & 25.463 & 17.399 & 45.123 & 50.637 & 50.883 & 25.012 \\
\hline $\begin{array}{l}\text { Kc. } \\
\text { Tanah }\end{array}$ & 9.145 & 8.615 & 3.674 & 5.886 & 5.887 & 6.259 \\
\hline $\begin{array}{l}\text { Kc. } \\
\text { Hijau }\end{array}$ & 6.065 & 5.617 & $(1.614)$ & $(1.455)$ & $(1.598)$ & 3.395 \\
\hline $\begin{array}{l}\text { Ubi } \\
\text { Jalar }\end{array}$ & 57 & $(584)$ & 2.670 & 3.573 & 4.566 & 3.232 \\
\hline $\begin{array}{l}\text { Ubi } \\
\text { Kayu }\end{array}$ & 5.750 & 6.706 & 8.507 & 22.341 & 36.559 & 22.873 \\
\hline Sagu & 220.434 & 247.872 & 243.568 & 244.570 & 210.653 & 340.028 \\
\hline $\begin{array}{l}\text { Buah- } \\
\text { buahan }\end{array}$ & 162.170 & 290.624 & 175.536 & 174.036 & 210.578 & 167.915 \\
\hline Sayuran & 211.871 & 236.575 & 102.350 & 117.787 & 189.014 & 177.878 \\
\hline Daging & 2.356 & 18.629 & 12.881 & 13.359 & 18.029 & 24.680 \\
\hline Telur & 3.332 & 3.781 & 12.450 & 14.568 & 14.213 & 11.470 \\
\hline Ikan & 45.710 & 62.584 & 85.126 & 88.397 & 111.969 & 41.072 \\
\hline & $\mathbf{9 6 3 . 2 6 6}$ & $\mathbf{1 . 1 2 4 . 8}$ & $\mathbf{8 9 2 . 1 0 1}$ & $\mathbf{8 9 9 . 0 8 5}$ & $\mathbf{1 . 0 0 6 . 8}$ & $\mathbf{9 9 0 . 3 2 8}$ \\
\hline
\end{tabular}

Sumber: BKP Prov. Riau (2017)

Data diatas menunjukkan dari semua komoditi pangan hanya komoditi jagung saja yang belum dapat terpenuhi. Oleh karena itu, dibutuhkan sebuah model untuk mengetahui apa saja faktorfaktor yang dapat mempengaruhi ketersediaan pangan komoditi jagung sehingga dapat diambil kebijakan dan keputusan yang tepat untuk BKP Provinsi Riau.

\section{Landasan Teori}

Pengertian tentang pangan menurut Undang-Undang Nomor 7 tahun 1996 adalah: Segala sesuatu yang berasal dari sumber hayati dan air, baik yang diolah maupun tidak diolah, yang diperuntukan sebagai makanan atau minuman bagi konsumsi manusia, termasuk bahan tambahan pangan, bahan baku pangan, dan bahan lain yang digunakan dalam proses penyiapan, pengolahan, dan atau pembuatan makanan dan minuman (Pasaribu, 2013).

Berdasarkan World Food Summit (Wright (2013) dikutip oleh Rizqiansyah, 2014), ketahanan pangan adalah ketersediaan setiap saat pasokan pangan dunia yang mencukupi bahan makanan pokok untuk mempertahankan perkembangan konsumsi makanan dan untuk mengimbangi fluktuasi produksi dan harga.

\section{Analisis Regresi Linear Berganda}

Model regresi linier berganda merupakan perluasan dari model regresi linier sederhana. Dengan memperluas model regresi linier dua atau tiga variabel, maka model regresi dengan variabel terikat $\mathrm{Y}$ dan $\mathrm{k}$ variabel bebas $\mathrm{X}_{1}, \mathrm{X}_{2}, \mathrm{X}_{3}, \ldots, \mathrm{X}_{\mathrm{k}}$ dapat dituliskan sebagai berikut (Atmaja, 2009):

$$
Y^{\prime}=\mathbf{a}+\mathbf{b}_{1} \mathbf{X}_{1}+\mathbf{b}_{2} \mathbf{X}_{2}+\ldots \ldots+\mathbf{b}_{n} \mathbf{X}_{n}+\mathbf{e}
$$

\section{Uji F dan Uji t}

Uji F digunakan untuk melihat pengaruh variabel independen secara keseluruhan atau bersama-sama terhadap variabel dependen (Budialim, 2013).

Uji $\mathrm{t}$ digunakan untuk melihat pengaruh variabel independen secara partial atau masingmasing terhadap variabel dependen..

\section{Metodologi Penelitian}

Untuk mendapatkan hasil penelitian yang baik diperlukan urutan langkah penelitian yang baik. Pada penelitian ini, tahap-tahap yang akan dilakukan dapat dilihat pada flow chart berikut: 


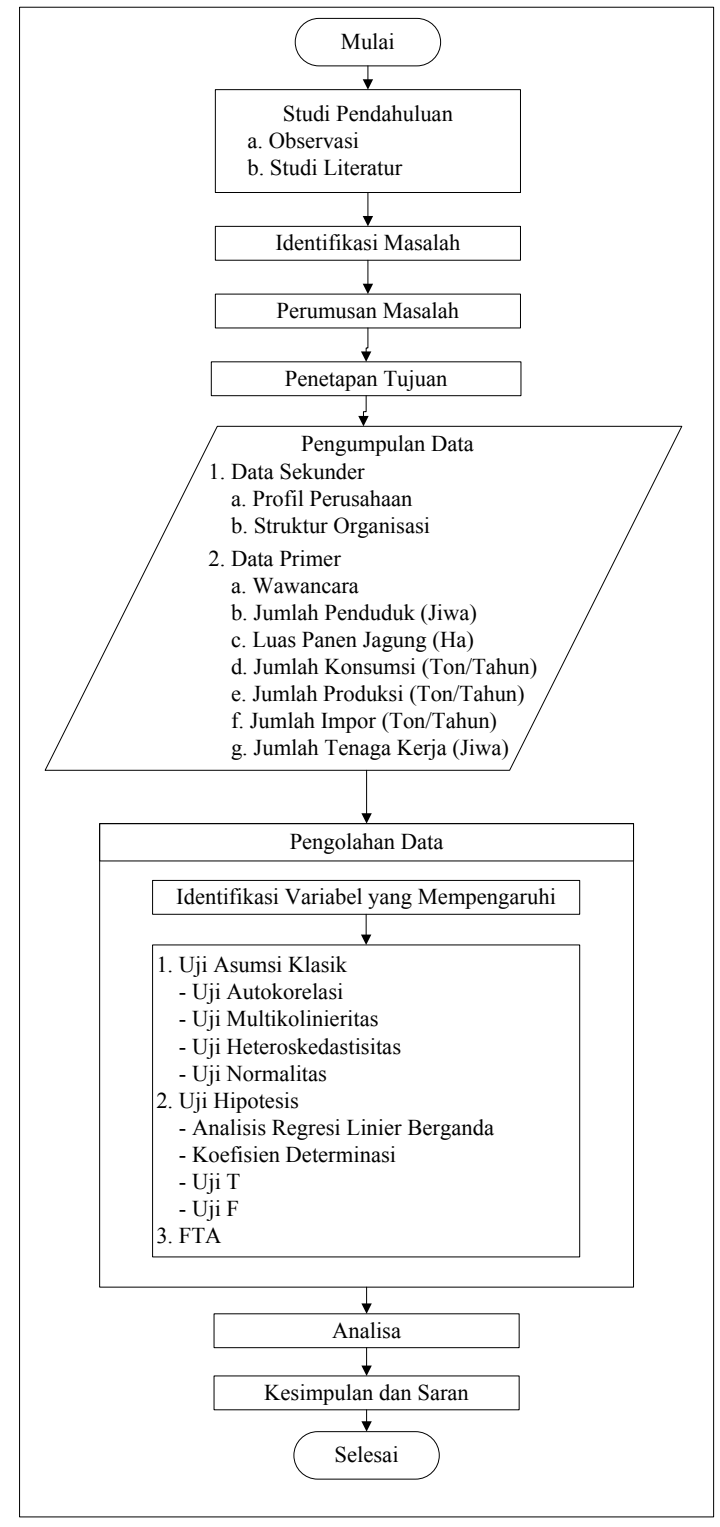

Gambar 1. Flow chart penelitian

\section{Hasil dan Pembahasan}

\section{Uji Autokorelasi}

Untuk mengidentifikasi ada atau tidaknya autokorelasi, dapat dilakukan pengujian durbinwatson. Pengujian melalui SPSS 16.0 menghasilkan nilai durbin watson (d) sebesar 1,833 , kemudian dilihat pada tabel durbin-watson $(\alpha=5 \%)$ dengan jumlah observasi $(\mathrm{N})$ sebanyak 11 dan jumlah variabel independen sebanyak 4 diperoleh nilai nilai DW berada $-2 \leq \mathrm{DW} \leq 2$. Adapun output SPSS 16.0 adalah sebagai berikut:
Tabel 2. Nilai durbin-watson

\begin{tabular}{|c|c|c|c|c|c|}
\hline \multirow{2}{|c|}{ Model } & R & R & Adjusted R & Std. Error of & Durbin- \\
& & Square & Square & the Estimate & Watson \\
\hline 1 & $0,996^{\text {a }}$ & 0,992 & 0,987 & 888,33499 & 1,833 \\
\hline
\end{tabular}

Sumber: SPSS (2017)

Berdasarkan studi literature, apabila nilai DW berada diantara $-2 \leq 1,833 \leq 2$ dapat disimpulkan tidaknya autokorelasi.

\section{Uji Multikolinieritas}

Uji multikolinieritas digunakan untuk menguji ada tidaknya hubungan linier diantara variabel-variabel independen dalam model regresi. Salah satu cara untuk mengetahui ada tidaknya multikolinieritas pada suatu model regresi adalah dengan melihat nilai toleransi dan VIF (varians inflation faktor). Jika nilai toleransi $>0,1$ dan VIF $>10$ maka terjadi multikolinieritas.

Tabel 3. Tolerance dan VIF untuk uji multikolinieritas

\begin{tabular}{|c|c|c|}
\hline \multirow{2}{*}{$\begin{array}{c}\text { Model }(\text { Dependent }= \\
\mathrm{x} 1)\end{array}$} & \multicolumn{2}{|c|}{ Collinearity Statistics } \\
\hline & Tolerance & VIF \\
\hline $\mathrm{x} 2$ & 0,414 & 2,417 \\
\hline $\mathrm{x} 3$ & 0,402 & 2,487 \\
\hline $\mathrm{x} 4$ & 0,906 & 1,103 \\
\hline \multirow{2}{*}{$\begin{array}{c}\text { Model }(\text { Dependent }= \\
\mathrm{x} 2)\end{array}$} & \multicolumn{2}{|c|}{ Collinearity Statistics } \\
\hline & Tolerance & \\
\hline $\mathrm{x} 1$ & 0,564 & 1,773 \\
\hline $\mathrm{x} 3$ & 0,564 & 1,774 \\
\hline $\mathrm{x} 4$ & 0,964 & 1,037 \\
\hline \multirow{2}{*}{$\begin{array}{c}\text { Model }(\text { Dependent }= \\
\text { x } 3)\end{array}$} & \multicolumn{2}{|c|}{ Collinearity Statistics } \\
\hline & Tolerance & \\
\hline $\mathrm{x} 1$ & 0,494 & 2,026 \\
\hline $\mathrm{x} 2$ & 0,508 & 1,970 \\
\hline $\mathrm{x} 4$ & 0,924 & 1,082 \\
\hline \multirow{2}{*}{$\begin{array}{c}\text { Model }(\text { Dependent }= \\
\mathrm{x} 4)\end{array}$} & \multicolumn{2}{|c|}{ Collinearity Statistics } \\
\hline & Tolerance & \\
\hline $\mathrm{x} 1$ & 0,484 & 2,067 \\
\hline $\mathrm{x} 2$ & 0,378 & 2,647 \\
\hline $\mathrm{x} 3$ & 0,402 & 2,487 \\
\hline
\end{tabular}

Sumber: SPSS (2017) 
Dari tabel di atas dapat diketahui bahwa nilai toleransi semua variabel independen yaitu, varabel 1 sampai variabel 4 memiliki Tolerance $>0,10$ dan $\mathrm{VIF}<10$, maka tidak terjadi multikolinieritas dan pengolahan dapat dilanjutkan.

\section{Uji Heteroskedastisitas}

Uji heteroskedastisitas dilakukan untuk melihat apakah ada atau tidaknya kesamaan varian.

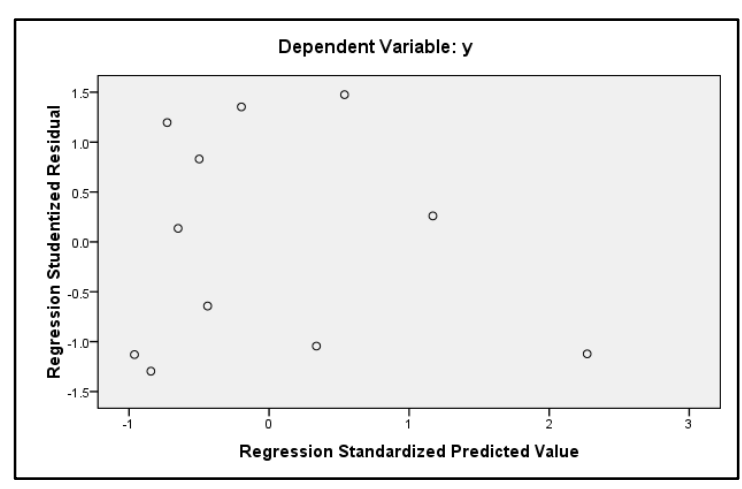

Gambar 2. Scatterplot uji heterokedastisitas

Berdasarkan pengolahan SPSS 16.0 maka didapatkan output seperti Gambar 4.5, terlihat titiktitk yang menyebar secara acak, tidak membentuk suatu pola tertentu yang jelas, serta tersebar baik di atas maupun di bawah angka 0 (nol) pada sumbu Y. Hal ini berarti tidak terjadi heterokedastisitas pada model regresi, sehingga model layak dipakai memprediksi ketersediaan pangan komoditi jagung Provinsi Riau.

\section{Uji Normalitas}

Berdasarkan hasil pengolahan menggunakan spss ver. 16, maka didapatkan hasil sebagai berikut:

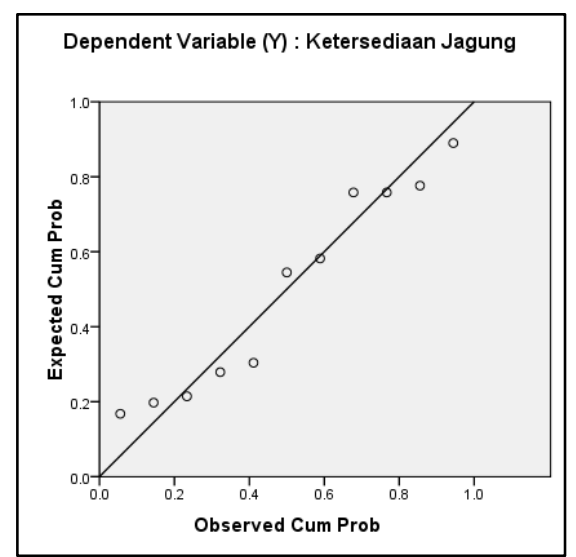

Gambar 3. Grafik normal plot ketersediaan jagung

Berdasarkan Gambar 4.3, Ketersediaan Jagung terdistribusi Normal, hal ini dapat dilihat dari tampilan grafik normal plot diatas yang titik menyebar dekat di sekitar garis diagonal serta penyebarannya mengikuti arah garis diagonal. Sehingga hal ini menunjukkan bahwa model persamaan layak dipakai karena telah memenuhi asumsi normalitas.

\section{Analisis Regresi Berganda}

Tabel 4. Hasil regresi linier berganda uji T

\begin{tabular}{|c|c|}
\hline \multicolumn{2}{|c|}{ Coefficients ${ }^{\mathrm{a}}$} \\
\hline Model & Koefisien Regresi \\
\hline (Constant) & $-6496,921$ \\
\hline Luas Panen (X1) & 2,105 \\
\hline Harga Domestik (X2) & 0,000 \\
\hline Jumlah Penduduk (X3) & 0,002 \\
\hline $\begin{array}{l}\text { Jumlah Tenaga Kerja } \\
\text { (X4) }\end{array}$ & 0,001 \\
\hline $\mathrm{R}^{2}$ & 0,992 \\
\hline Uji F & \\
\hline Fhitung & 190,270 \\
\hline Ftabel & \\
\hline t-tabel & \\
\hline
\end{tabular}

Sumber: SPSS (2017)

Berdasarkan tabel di atas, dapat diperoleh rumus regresi yaitu, $\mathrm{Y}=-6496,921+2,105 \mathrm{X}_{1}-0,000 \mathrm{X}_{2}$ $+0,002 X_{3}+0,001 X_{4}$. Maka data dapat dianalisa :

1. Konstanta $=-6.496,921$

Jika faktor luas panen, harga domestik jagung, jumlah penduduk dan jumlah tenaga kerja adalah 0, maka akan menyebabkan penurunan ketersediaan jagung sebesar $6.496,921$ Ton. Konstanta yang negatif tidak perlu dipermasalahkan dan bisa diabaikan selama telah memenuhi syarat uji asumsi klasik.

2. Koefisien $\mathrm{X}_{1}=2,105$

Jika faktor luas panen mengalami peningkatan sebesar 1 (Ha) sementara faktor lain tetap, maka akan menyebabkan kenaikan ketersediaan jagung d Provinsi Riau sebesar 2,105 Ton.

3. Koefisien $\mathrm{X}_{2}=0,000$

Pada daktor harga domestik jagung, tidak terdapat pengaruh positif atau negatif antara harga domestik jagung dengan ketersediaan jagung. Hal ini dikarenakan bahwa harga jagung di pengaruhi oleh kondisi di pasaran.

4. Koefisien $\mathrm{X}_{3}=0,002$

Jika faktor jumlah penduduk mengalami peningkatan sebesar 1000 jiwa sementara faktor lain tetap, maka akan menyebabkan kenaikan ketersediaan jagung sebesar 2 Ton.

5. Koefisien $\mathrm{X}_{4}=0,001$

Jika faktor tenaga kerja mengalami peningkatan sebesar 1000 jiwa sementara 
faktor lain tetap, maka akan menyebabkan kenaikan ketersediaan jagung sebesar 1 ton.

\section{Uji t}

Tabel 5. Output uji t

\begin{tabular}{|l|r|r|}
\hline \multicolumn{3}{|c|}{ Coefficients $^{\mathbf{a}}$} \\
\hline \multicolumn{1}{|c|}{ Model } & t-hitung $^{\text {S-hignifikan }}$ \\
\hline (Constant) & $-1,107$ & 0,348 \\
\hline Luas Panen (X1) & 21,517 & 0,000 \\
\hline Harga Domestik (X2) & 0,431 & 0,682 \\
\hline \begin{tabular}{l|r|} 
Jumlah Penduduk (X3) \\
Jumlah Tenaga Kerja \\
(X4)
\end{tabular} & 0,707 & 0,013 \\
\hline
\end{tabular}

Sumber: Pengolahan Data (2017).

Diketahui :

Df $=6$

$\mathrm{t}_{(0,05.6)}=2,447$

Maka:

1. Luas panen, $\mathrm{t}_{\text {hitung }}<\mathrm{t}_{\text {tabel }}(21,517>2,447)$

Berarti $\mathrm{H}_{1}$ diterima, sehingga luas panen ada pengaruh yang signifikan terhadap ketersediaan jagung Provinsi Riau.

2. Harga domestik jagung, $t_{\text {hitung }}<t_{\text {tabel }}(0,431<$ 2,477)

Berarti $\mathrm{H}_{0}$ diterima, sehingga harga domestik jagung tidak ada pengaruh yang signifikan terhadap ketersediaan jagung Provinsi Riau.

3. Jumlah penduduk, $t_{\text {hitung }}<t_{\text {tabel }}(3,501>2,447)$ Berarti $\mathrm{H}_{1}$ diterima, sehingga jumlah penduduk ada pengaruh yang signifikan terhadap ketersediaan jagung Provinsi Riau.

4. Jumlah tenaga kerja, $t_{\text {hitung }}<t_{\text {tabel }}$ $(0,707<2,447)$ Berarti $\mathrm{H}_{0}$ diterima, sehingga jumlah tenaga kerja tidak ada pengaruh yang signifikan terhadap ketersediaan jagung Provinsi Riau.

\section{Uji F}

Tabel 6. Print Out Uji F

\begin{tabular}{|c|c|c|c|c|c|}
\hline \multicolumn{6}{|c|}{ ANOVA $^{\mathbf{a}}$} \\
\hline Model & $\begin{array}{c}\text { Sum of } \\
\text { Square } \\
\text { S }\end{array}$ & Df & $\begin{array}{c}\text { Mean } \\
\text { Square }\end{array}$ & F & Sig. \\
\hline Regression & 9 & & $\begin{array}{c}190,27 \\
0\end{array}$ &, $000^{\text {b }}$ \\
\hline Residual & & & & & \\
\hline Total & \multicolumn{6}{|c|}{ a. Dependent Variable: y } \\
\hline \multicolumn{6}{|c|}{ b. Predictors: (Constant), } \\
\hline \multicolumn{6}{|c|}{} \\
\hline
\end{tabular}

Sumber: Pengolahan Data (2017).

Berdasarkan hasil uji serempak seperti pada tabel di atas diperoleh $F_{\text {hitung }}$ sebesar 190,270 dengan signifikansi $0,000<0,05$. Dengan demikian menunjukan bahwa ada pengaruh yang nyata antara faktor luas panen, harga domestik jagung, jumlah penduduk dan jumlah tenaga kerja terhadap ketersediaan bahan pangan komoditi jagung Provinsi Riau.

Besarnya pengaruh secara serempak variabel faktor luas panen, harga domestik jagung, jumlah penduduk dan jumlah tenaga kerja terhadap ketersediaan bahan pangan komoditi jagung Provinsi Riau dapat diketahui dari harga koefisien determinasi ganda $\left(\mathrm{R}^{2}\right)$. Berikut ini disajikan print out koefisien determinasi ganda.

Tabel 7. Koefisien determinasi

\begin{tabular}{|l|c|c|c|c|c|}
\hline $\begin{array}{l}\text { Mod } \\
\text { el }\end{array}$ & $\mathbf{R}$ & $\begin{array}{c}\text { R } \\
\text { Square }\end{array}$ & $\begin{array}{c}\text { Adjusted } \\
\text { R Square }\end{array}$ & $\begin{array}{c}\text { Std. Error } \\
\text { of the } \\
\text { Estimate }\end{array}$ & $\begin{array}{c}\text { Durbin- } \\
\text { Watson }\end{array}$ \\
\hline 1 & $0,996^{\mathrm{a}}$ & 0,992 & 0,987 & 888,33499 & 1,833 \\
\hline
\end{tabular}

Sumber: Pengolahan Data (2017).

Berdasarkan tabel di atas tampak bahwa nilai $R$-square sebesar 0,992 yang berarti bahwa variabel faktor luas panen $\left(\mathrm{X}_{1}\right)$, faktor harga domestik jagung $\left(\mathrm{X}_{2}\right)$, faktor jumlah penduduk $\left(\mathrm{X}_{3}\right)$ dan faktor jumlah tenaga kerja $\left(\mathrm{X}_{4}\right)$ berpengaruh terhadap ketersediaan bahan pangan komoditi jagung Provinsi Riau (Y) yaitu sebesar $99,2 \%$, sedangkan selebihnya yaitu $0,8 \%$ dipengaruhi oleh faktor lain diluar faktor yang telah dikaji oleh peneliti ini.

\section{Analisa FTA}

Analisa FTA dilakukan berdasarkan variabel yang mempengaruhi keteresediaan bahan pangan jagung.

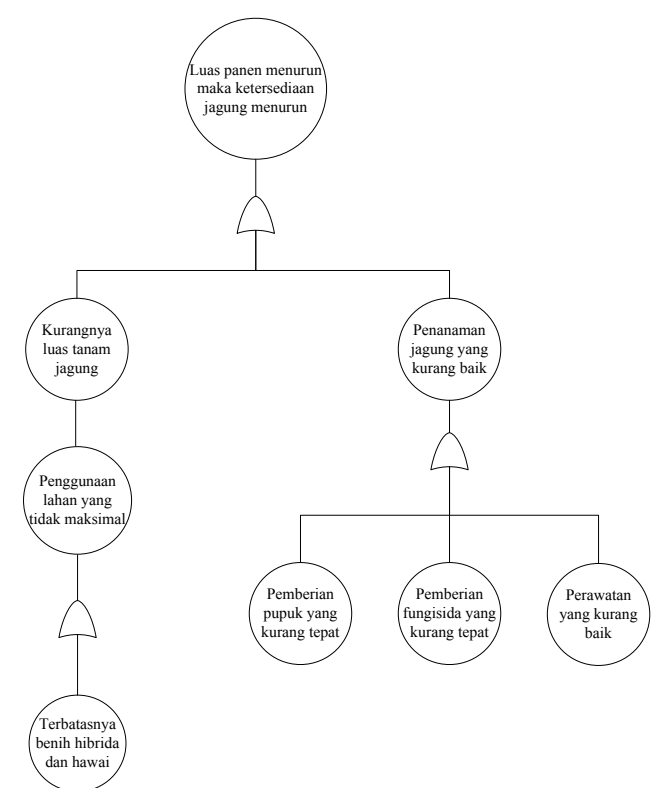

Gambar 4. Luas panen mempengaruhi ketersediaan jagung 


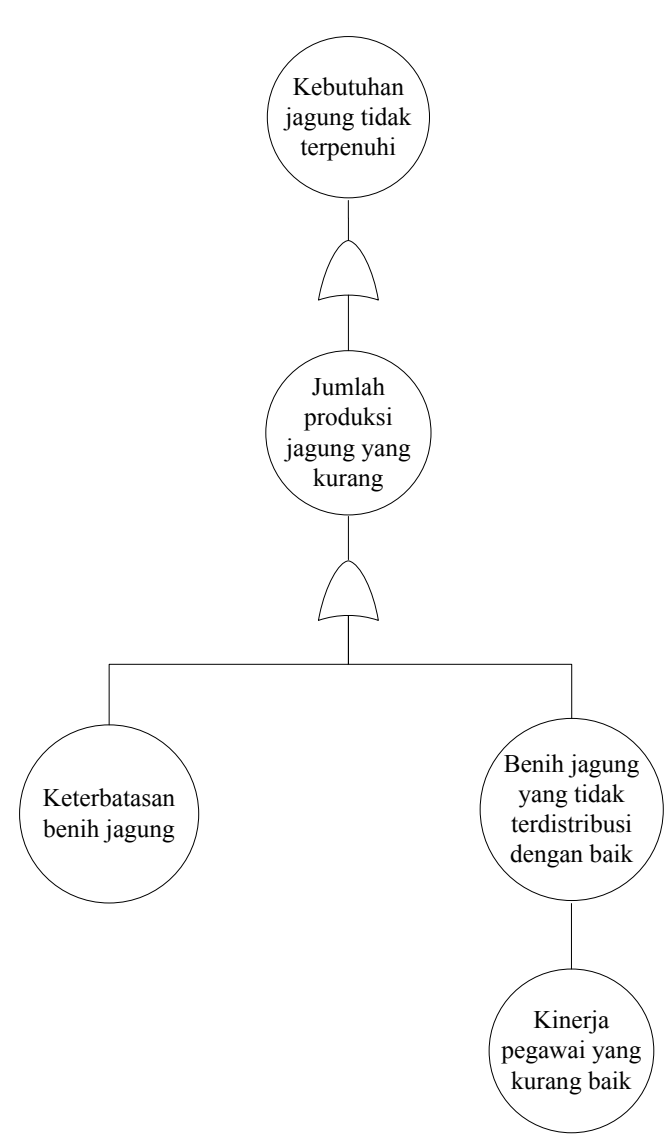

Gambar 5. Pengaruh jumlah penduduk terhadap ketersediaan jagung

Berdasarkan hasil dari FTA dapat disimpulkan terdapat 2 kebijakan yang dapat dilakukan oleh pemerintah, yaitu:

1. Kebijakan pemberian subsidi benih jagung hibrida dan hawai kepada petani jagung.

2. Kebijakan evaluasi kinerja pegawai dalam pendistribusian benih subsidi.

Untuk mensukseskan kebijakan tersebut, dapat dilakukan dengan cara mengadakan penyuluhan-penyuluhan kepada petani-petani tentang pemberian subsidi benih jagung di tiap-tiap desa yang ada di Provinsi Riau.

\section{Kesimpulan}

Hasil penelitian ini dapat disimpulkan bahwa variabel-variabel yang mempengaruhi ketersediaan bahan pangan (komoditi jagung) adalah luas panen, harga domestik jagung, jumlah penduduk dan jumlah tenaga kerja (petani jagung). Dimana 99,2\% variabel terikat yaitu Ketersediaan Jagung dapat dijelaskan oleh variabel-variabel bebas yaitu Luas Panen, Harga Domestik, Jumlah Penduduk dan Tenaga Kerja. Sedangkan sisanya sebesar $0,8 \%$ dijelaskan oleh variabel lain yang tidak dimasukkan ke dalam model. Sehingga dari hasil tersebut dapat diambil kebijakan dan keputusan yang tepat untuk Badan Ketahanan Pangan Provinsi Riau yaitu sebagai berikut:

1. Kebijakan pemberian subsidi benih jagung hibrida dan hawai kepada petani jagung.

2. Kebijakan evaluasi kinerja pegawai dalam pendistribusian benih subsidi.

Dengan kebijakan di atas, maka diharapkan dapat meningkatkan ketersediaan bahan pangan pada komoditi jagung guna untuk memenuhi kebutuhan pangan jagung bagi penduduk di Provinsi Riau.

\section{Daftar Pustaka}

[1] Avianda, Dea. Strategi Peningkatan Produktivitas Di Lantai Produksi Menggunakan Metode Objective Matrix (OMAX). Jurnal Online Institut Teknologi Jurusan Teknik Industri Itenas No.04 Vol. 01 ISSN: 2338-5081. Bandung. 2014.

[2] Atmaja, Lukas Setia. Statistika Untuk Bisnis dan Ekonomi. CV Andi OFFSET. Yogyakarta. 2009.

[3] Budialim, G. Pengaruh kinerja Keuangan Dan Risiko Terhadap Return Saham Perusahaan Sektor Consumer Goods Di Bursa Efek Indonesia Periode 2007-2011.Jurnal Ilmiah Mahasiswa Universitas Surabaya Vol.2 No.1. 2013.

[4] Ghozali, Imam. Aplikasi Analisis Multivariate dengan Program SPSS edisi 3. Badan Penerbit Universitas Diponegoro. Semarang. 2006.

[5] Ghozali, Imam. Aplikasi Analisis Multivariate dengan Program SPSS edisi 21. Badan Penerbit Universitas Diponegoro. Semarang. 2013.

[6] Mona, Margaretha G, Kekenusa, John S, dan Prang, Jantje D.Penggunaan Regresi Linear Berganda untuk Menganalisis Pendapatan Petani Kelapa. Jurnal Ilmiah JdC, Vol. 4, No. 2, September 2015.Manado. 2015.

[7] Pasaribu, Rowland B. F. Ketahanan Pangan Nasional. Gunadarma Publishing. Jakarta. 2013.

[8] Prabowo, Rossi. Kebijakan Pemerintah Dalam Mewujudkan Ketahanan Pangan Di Indonesia. Jurnal Ilmiah Fakultas Pertanian Universitas Wahid Hasyim Mediagro $62 \mathrm{Vol}$ 6. No 2. Semarang. 2010.

[9] Reddy, P.Ramesh. A Multiple Linear Regression Approach for the Analysis of Stress Factors of Faculty in Higher Educational Institutions. International Journal of Mathematics And its Applications Volume 3, ISSN: 2347-1557. India. 2015. 
[10] Rizqiansyah, Rizal. Pemodelan Dan Simulasi Berbasis Agen Untuk Sistem Ketahanan Pangan Pokok Beras Di Jawa Barat. Jurnal Online Institut Teknologi Nasional Jurusan Teknik Industri ISSN: 2338-5081 No.04 Vol.02. Bandung. 2014.

[11] Sarwono. 12 Jurus Ampuh SPSS untuk Riset Skripsi. Elexmedia Komputindo Kompas Gramedia. Jakarta. 2013.

[12] Suliyanto. Ekonometrika Terapan. CV Andi OFFSET. Yogyakarta. 2011.

[13] Susilowati, Heni. Faktor-Faktor Yang Mempengaruhi Ketahanan Pangan Rumah Tangga Miskin Di Kecamatan Srandakan Bantul. Skripsi Program Studi Pendidikan Ekonomi Fakultas Ekonomi Universitas Negeri Yogyakarta. Yogyakarta. 2014.

[14] Tambunan, Tulus. Ketahanan Pangan Di Indonesia Inti Permasalahan Dan Alternatif Solusinya. Jurnal Ilmiah Pusat Studi Industri Dan UKM, Universitas Trisakti Kadin Indonesia. Jakarta. 2008.

[15] Usman, Husaini. Pengantar Statistika Edisi Kedua. PT. Bumi Aksara. Jakarta. 2006. 